\title{
PARA PENSAR A RECEPÇÃO PUBLICITÁRIA: ANOTAÇÕES EMPÍRICAS SOBRE PROCEDIMENTOS METODOLÓGICOS
}

\author{
TO THINK ABOUT ADVERTISING RECEPTION: EMPIRICAL NOTES \\ ABOUT METHODOLOGICAL PROCEDURES
}

\section{PARA PIENSAR LA RECEPCIÓN PUBLICITARIA: NOTAS EMPÍRICAS SOBRE PROCEDIMIENTOS METODOLÓGICOS}

\author{
Filipe Bordinhão dos Santos \\ Doutorando PPGComunicação UFSM \\ filipebordinhao@hotmail.com
}

\begin{abstract}
Resumo
O artigo propõe-se a discutir sobre os estudos da recepção publicitária, tendo em vista a necessidade de aprimorarmos bases referenciais que viabilizem compreender a relação entre a publicidade e os receptores. Para isso, o trabalho parte de apontamentos empíricos levantados em um estudo de recepção já concluído. A análise apresenta três pontos cruciais para o desenvolvimento de protocolos metodológicos que elucidem a investigação da recepção da publicidade: o fluxo publicitário, a apropriação de representações e a baixa memória do receptor. A partir da reflexão, percebemos, empiricamente, que ainda há grandes desafios para o aperfeiçoamento das pesquisas que estudam a relação entre os atores sociais e os anúncios publicitários, sobretudo quanto aos procedimentos metodológicos de observação e análise.
\end{abstract}

Palavras-chave: Recepção da Publicidade; Desafios Metodológicos; Fluxo Publicitário.

\begin{abstract}
The article purposes to discuss about advertising reception studies, considering our need to improve referential bases to enable the understanding of the relation between advertising and receptors. For this, the research starts with some empirical notes from a concluded reception study. The analysis introduces three crucial points for the methodological protocols development which elucidate the advertising reception investigation: advertising flow, appropriation of representations and receptor's low memory. From the reflection, we realized, empirically, that there are still great challenges to enhance the researches that study the relation among social actors and advertisement, especially as for the methodological procedures of observation and analysis.
\end{abstract}

Key words: Advertising Reception; Methodology; Advertising Flow.

\section{Resumen}

El artículo se propone discutir los estudios de recepción de publicidad, teniendo en cuenta la necesidad de aprimorarmos bases referenciales que permiten entender la relación entre la publicidad y los receptores. Para ello, el artículo presenta notas empíricas planteadas en un estudio de recepción ya terminado. El análisis presenta tres puntos cruciales para el desarrollo de protocolos metodológicos para dilucidar la investigación de la recepción de la publicidad: el flujo de publicidad, la propiedad de las representaciones y de poca memoria 
del receptor. A partir de la reflexión, nos damos cuenta, empíricamente, que aún existen importantes retos para mejorar la investigación el estudio de la relación entre los actores sociales y los comerciales, en especial los procedimientos metodológicos de observación y análisis.

Palabras clave: Recepción de Publicidad; Desafíos metodológicos; Flujo de la Publicidad

\section{BREVE REFLEXÃO (EPISTEMOLÓGICA) SOBRE O CAMPO DA COMUNICAÇÃO}

Para início de conversa, precisamos relembrar o quanto o campo das Ciências da Comunicação é questionado, o que propicia muitos debates em busca de fronteiras menos tênues, que o definam claramente perante a grande área das Ciências Sociais e Humanas. A discussão epistemológica surge, sobretudo, devido a particularidades do próprio campo, relacionadas à interdisciplinaridade, as quais, ao mesmo tempo em que o caracterizam, o inserem em um horizonte aberto, por vezes confuso, em relação a áreas do conhecimento já consolidadas, como a Sociologia e a Antropologia. Outra questão está associada ao fato de o objeto de estudo da comunicação ser algo presente no cotidiano, dominado pelo senso comum das pessoas, o que permite a todos manuseá-lo e experimentá-lo. Essa situação gera certa falta de reconhecimento e de credibilidade das pesquisas da área, tratadas, em muitos casos, como superficiais e sem relevância científica no espaço acadêmico.

Ainda, a especificidade temporal da dinâmica do processo comunicativo - dos seus objetos - exige que saibamos lidar com uma realidade mutável e, por vezes, difícil de apreender. A situação decorre das avançadas tecnologias da comunicação e, consequentemente, da velocidade de circulação das informações. Esse fato propicia outra temporalidade social, a qual, estimulada pela técnica, afeta profundamente a experiência individual e coletiva, redefinindo o tempo e o espaço em que vivemos. Ou seja, "os acontecimentos estão sempre à frente da possibilidade de que sejam interpretados pelos indivíduos, assim como o derrame social das tecnologias da comunicação está à frente da sua interpretação pelas formas individuais e coletivas de consciência” (SODRÉ, 20017, p.19).

Portanto, "esta é a realidade com que tem de lidar a comunicação, enquanto que às clássicas ciências sociais se reserva um estatuto temporal, onde é possível à consciência interpretar e saber" (ibidem). No entanto, também é necessário fazer a mea-culpa, visto que o contexto de instabilidade é reflexo da postura de muitos pesquisadores da Comunicação. Afinal, conforme Sodré (2007, p.16), é preciso que os estudiosos "se preocupem mais com a precariedade teórica de suas análises". Com base nesse argumento, o que pretendemos 
ressaltar é que ainda observa-se certo desinteresse pela definição do campo e de suas bases teóricas referencias. Nesse sentido, França reconhece, dentro das Teorias da Comunicação, "alguma negligência e até mesmo um certo ostracismo no tratamento dos fundamentos teóricos de nossa área; uma 'quase falta de nobreza' na discussão do objeto da comunicação, das suas bases teóricas e metodológicas" (2001, p.2). Como consequência, percebemos, ainda, uma falta de coesão entre autores e a tentativa de definição de aspectos teóricos vitais da área.

\begin{abstract}
A comunicação é concebida como instrumento (rádio, jornal, revista, televisão, internet e outros) a ser analisado, ou então como mero pretexto para a resolução de um problema da disciplina em questão, tal como o de suprir uma carência analítica frente à multiplicação dos dispositivos informacionais na cultura contemporânea. (SODRÉ, 2007, p.15).
\end{abstract}

Após a breve explanação sobre a conjuntura de nosso campo, não podemos desconsiderar que o contexto epistemológico da comunicação - aqui apresentado em linhas gerais e associado ao fato de ser uma Ciência ainda jovem - também é responsável pelas fragilidades que caracterizam certas linhas de pesquisa que investigam os processos comunicacionais, entre elas a da comunicação publicitária. Neste caso, abordagens restritas ao viés do marketing e da psicologia produziram, historicamente, uma visão limitada e determinista da prática publicitária, o que, inclusive, privou-a, muitas vezes, de valor científico. No entanto, “já se foi o tempo em que os anúncios publicitários carregavam o estigma de objetos de estudo ilegítimos ou eram incapazes de atrair a atenção de pesquisadores desligados da prática profissional” (MAZETTI, 2011, p.1).

Dessa forma, o presente trabalho busca discutir questões metodológicas a respeito da recepção da publicidade, tendo como base os achados empíricos de um estudo já concluído ${ }^{1}$. Nossa proposta é de caráter reflexivo e não tem a intenção de findar a discussão, mas a de colocar em pauta tais apontamentos e estimular o avanço e a definição de um protocolo teóricometodológico de investigação empírica da mensagem publicitária. Inicialmente, situados na vertente latino-americana dos Estudos Culturais, refletimos teoricamente sobre a dimensão social e simbólica da publicidade e o seu processo de recepção dentro da ideia de um fluxo contínuo de anúncios. Com este cenário, na sequência, analisamos três importantes pontos para pensarmos a recepção publicitária: o fluxo publicitário, a apropriação de representações e a baixa memória de anúncios do receptor.

\footnotetext{
${ }^{1}$ SANTOS, F. B. Masculinidade em anúncio(s): recepção publicitária e identidade de gênero. Dissertação (Mestrado em Comunicação), Universidade Federal de Santa Maria, Santa Maria/RS, 2012. Disponível em: $<$ http://w3.ufsm.br/poscom/wp-content/uploads/2013/05/Disserta\%C3\%A7\%C3\%A3o-Filipe.pdf. $>$. Acesso em: 21 fev. 2014.
} 


\section{2. (RE)PENSANDO A PUBLICIDADE: ASPECTOS TEÓRICOS}

As limitações teórico-metodológicas enfrentadas pelos estudos da comunicação publicitária, ainda hoje, são consequência de abordagens limitadas que dominaram historicamente o campo de pesquisa. Tal situação é decorrente da baixa produtividade de teorias que problematizem, sistematizem e sustentem a complexidade do fenômeno publicitário imbricado ao viés cultural. Provavelmente, essa condição seja o reflexo de perspectivas superficiais, do ponto de vista das problemáticas propostas, focadas apenas em análises econômicas ou isoladas na mensagem publicitária.

Nosso questionamento não se concentra no privilégio dado à produção ou à mensagem publicitária, mas na carência dessas pesquisas em desenvolver um ponto de vista sociocultural, perspectiva preconizada pelos estudos de recepção. Ressaltamos que tal cenário se estabelece, também, devido aos próprios profissionais e pesquisadores aceitarem uma visão polarizada e teoricamente pouco desenvolvida de suas áreas práticas de atuação. Essa ideia reforça a (quase) inexistência de concepções teóricas sobre a publicidade e, por conseguinte, a falta de consolidação do campo de estudos. Com vistas à superação da problemática, entendemos ser preciso reconhecer a publicidade como processo imerso em um contexto efetivamente cultural e de caráter interdisciplinar, independentemente da temática de pesquisa adotada.

Jacks (2002) explicita a situação através do levantamento das pesquisas realizadas nos Programas de Pós-Graduação em Comunicação no Brasil, na década de 1990, o qual detectou que os estudos alocavam-se em dois eixos de análise: 1) a perspectiva econômica funcional, que buscava verificar a funcionalidade e a eficácia econômica da publicidade como uma técnica de venda; 2) a crítica denuncista, que tinha como questionamento e crítica o poder de manipulação e alienação da publicidade. Nessas abordagens há a compreensão de "que o mundo social é unicamente determinado pelas condições criadas pelas atividades publicitárias, desconsiderando-se outros condicionantes macro e microssociais que fazem parte desta relação" (PIEDRAS, 2009, p.21).

Nesse sentido, ainda há necessidade de estabelecer-se uma discussão de caráter epistemológico, que entenda a natureza multifacetada da publicidade e ultrapasse as questões puramente econômicas, considerando, sobretudo, o contexto da sociedade contemporânea. Deve-se compreender a publicidade articulada aos contextos sociais nos âmbitos macro e micro, nos quais os atores estão em constante socialização, realizando práticas e construindo as suas identidades. Segundo Jacks, a superação das fragilidades das pesquisas está 
condicionada ao "desenvolvimento de teorias e metodologias adequadas para pensar o fenômeno da publicidade no mundo contemporâneo" (2001, p.211), fato que parece ter sido negligenciado antes mesmo de constituir-se uma definição.

[...] são poucas as reflexões voltadas para o exame sistemático de um discurso tão central quanto o publicitário. No campo da Comunicação, em particular, e das Ciências Sociais, em geral, a publicidade deveria aparecer como tema de interesse central para pesquisadores, pois estudar imagens, valores e ideologias que essas mensagens expressam, ocupando espaços urbanos, páginas de revistas e jornais se misturando às produções de rádio, televisão e cinema, é buscar conhecer valores, conceitos, modelos de ser, agir e se relacionar na sociedade contemporânea. (ROCHA em prefácio de GASTALDO, 2013, p.11).

Contudo, o problema não está limitado apenas à falta de produções acadêmicas que discutam a publicidade. Ao resgatarmos a história do desenvolvimento das Teorias da Comunicação, percebemos que o discurso publicitário ganhou espaço em diversas correntes teóricas desde os princípios funcionalistas. $\mathrm{Na}$ verdade, nos referimos ao fato de a produção acadêmica contemporânea voltada à publicidade estar bastante isolada em artigos, o que, por falta de sistematização e diálogo de perspectivas, não possibilita a formulação de bases mais concretas para a elaboração de uma Teoria da Publicidade, a exemplo daquelas que sustentam e embasam o debate no campo jornalístico (LONDERO, 2011). Por conta disso, não raro, deparamo-nos com discussões que ainda buscam definir a publicidade, na tentativa de sair da inércia conceitual que a trata, exclusivamente, como um instrumento econômico.

Do mesmo modo, "a ausência de paradigmas sedimentados no campo da publicidade gera uma confusão entre as diferentes abordagens adotadas pelos pesquisadores, o que desestimula o diálogo acadêmico e obscurece possíveis caminhos de investigação" (MAZZETI, 2011, p.3). Essa noção pode ser uma consequência da falta de espaços acadêmicos específicos que concentrem, articulem e proponham uma rede de pesquisadores das diferentes perspectivas da área - como é o caso do Encontro Nacional de Pesquisadores em Publicidade e Propaganda ${ }^{2}$, no Brasil, que tem o objetivo de propor discussões frutíferas que teorizem e embasem nosso campo de estudos a partir da sistematização de diferentes vertentes e perspectivas investigativas.

\footnotetext{
${ }^{2}$ Evento acolhido, desde 2010, pelos docentes da linha de pesquisa "Consumo e Usos Midiáticos nas Práticas Sociais", do Programa de Pós-Graduação em Ciências da Comunicação, que compõe o Departamento de Relações Públicas, Propaganda e Turismo (CRP) da Escola de Comunicações e Artes (ECA) da Universidade de São Paulo (USP). Configura-se como a principal atividade dos pesquisadores em Publicidade e Propaganda e Comunicação e Consumo do Brasil, a qual ocorre anualmente. Disponível em: $<$ http://www.eca.usp.br/Propesq/apresentacao.html>. Acesso em: 21 de fev. 2014.
} 
Conforme afirma Rocha (1995), é preciso que o "mundo da publicidade" cause-nos inquietude, sendo pensado como um "registro eloquente da experiência social contemporânea" (idem, 2006, p.11), uma maneira de conhecermos a nossa própria sociedade. Esse entendimento estimula reflexões teóricas densas sobre as práticas publicitárias, reconhecendo os anúncios como um fenômeno verdadeiramente social e, portanto, um produto cultural. É a partir da perspectiva dos Estudos Culturais que julgamos possível desvendar o (imenso) universo publicitário, cada vez mais presente em nosso cotidiano, e a sua relação com as diferentes esferas da sociedade. Ou seja, percebemos a narrativa publicitária como parte e fruto do fazer social e da realidade dos sujeitos.

\begin{abstract}
A propaganda comercial produz há décadas um rico, vasto e complexo material de investigação. Suas relações com a economia e a cultura, suas tentativas de persuadir o público e sua vocação para oferecer representações culturais estão mergulhadas em ambivalências, tensões e contradições que estão presentes também em outras áreas do tecido social. Explicitar, debater e desenvolver estas perspectivas teóricas multidisciplinares é fundamental para a evolução dos estudos sobre a publicidade no campo da comunicação. (MAZETTI, 2011, p. 11).
\end{abstract}

Nesse ínterim, destacamos a importância de abarcar outros aspectos que envolvam o processo publicitário, como: os valores de quem produz a mensagem e aqueles que circulam socialmente (acionados para compor o discurso publicitário); os sentidos agenciados nos anúncios; as mediações que balizam a relação dos receptores com a publicidade. Assim, acreditamos ser necessário um eixo teórico que articule as noções econômicas e culturais da publicidade, tendo em vista a sua atual configuração como um fenômeno cultural e social contemporâneo. Como exemplo dos aportes para se trabalhar nessa perspectiva, Casaqui destaca a Teoria das Mediações de Martín-Barbero, a qual define como uma associação que "busca contemplar fenômenos que tensionam os limites da publicidade, mantendo o sentido da comunicação persuasiva vinculada ao consumo, porém com modos complexos de configuração discursiva e de interlocução com os sujeitos identificados como consumidores". (2011, p. 133).

Embora a perspectiva socioeconômica tenha se desenvolvido e ganhado interesse científico mais recentemente no campo dos Estudos Culturais, devido ao boom midiático e do consumo das últimas décadas, a sua relevância já era observada nos estudos de um dos seus precursores, Raymond Willians, ainda na década de 1960. Naquela época, o autor alertava que a comunicação publicitária extrapolara a fronteira das transações econômicas e passava a ser um espaço que promove valores pessoais e sociais. Para ele, tal noção somente será 
compreendida "se pudermos desenvolver um tipo de análise total onde os fatores econômicos, sociais e culturais sejam visivelmente relacionados" (apud LONDERO, 2011, p. 15).

A publicidade configura-se como um expoente objeto de estudo, uma vez que retrata e dissemina os valores e as ideias vigentes dos períodos históricos da sociedade. A análise dos anúncios contemporâneos possibilita entender como os diversos padrões de sociabilidade, que historicamente circularam no âmago social, são redefinidos e recebem novo status na e pela narrativa publicitária. Nesse sentido, ainda que a publicidade possa ser restringida a um estímulo às vendas, igualmente ela "pode ser entendida como um processo comunicativo, cujas mensagens persuasivas são produzidas e recebidas em contextos contraditórios, implicados tanto pelo sistema hegemônico da estrutura econômica quanto pelas práticas culturais dos sujeitos" (PIEDRAS, 2009, p.20).

Assim, percebe-se a importância de investigá-la a partir do viés de quem a recebe e confere sentido social ao seu discurso - o receptor. Por conta disso, adotamos a perspectiva que relaciona o fenômeno publicitário aos aspectos culturais (Estudos Culturais) para compreender a sua dinâmica, pois, ao "considerarmos simultaneamente as dimensões econômica, política e cultural na análise da publicidade, chegamos a sua definição como fenômeno cultural cuja natureza é multifacetada" (PIEDRAS, 2009, p. 59). Dessa forma, reconhecem-se os elementos, os valores culturais reeditados pelos anúncios (anteriormente aceitos e reproduzidos socialmente) e a forma como são novamente significados e apropriados pelos sujeitos, considerando que "os elementos de uma cultura e suas significações podem ser utilizados para criar em planos múltiplos e entrelaçados a mensagem contida no anúncio" (ROCHA, 1995, p.85).

\section{NOTAS SOBRE OS ESTUDOS DE RECEPÇÃO EM PUBLICIDADE}

A baixa produtividade de pesquisas acadêmicas (dissertações e teses) sobre a publicidade, que caracterizou a década de 1990, no Brasil, segundo aponta o levantamento realizado por Jacks (2002), parece refletir, ainda hoje, sob o cenário investigativo da comunicação publicitária. Isso porque, como se sabe, em muitos casos são tais trabalhos os que geram novas questões, propõem modelos teórico-metodológicos e contribuem com outras publicações da área. A presente situação fragiliza o campo de estudo, afinal, "na medida em que se multiplicam as vias de circulação e as formas de apropriação e (re)produção da publicidade, os papéis das mensagens, produtos e receptores merecem uma atenção diferenciada" (OLIVEIRA-CRUZ, 2013, p. 14). 
No que diz respeito aos estudos empíricos, o cenário é considerado ainda mais preocupante, pois o uso da publicidade em estudos de recepção na comunicação manteve-se escassa também nos anos 2000 (JACKS, 2010). Nas duas décadas aqui consideradas (19902009), foram apenas dezenove trabalhos empíricos de recepção que tiveram a publicidade como objeto de investigação. Para a autora, embora haja visivelmente um acréscimo quantitativo na produção, isso se torna inexpressivo quando se leva em consideração o aumento do número de programas de pós-graduação em Comunicação no Brasil. Do mesmo modo, pouco se avançou qualitativamente, em especial na conceituação e em termos metodológicos. Destacamos que, com base no conhecimento sobre a produção no campo, se atualizarmos os dados com informações dos últimos quatro anos (2010-2013), é possível perceber que o cenário se mantém semelhante. Portanto, não se evidencia crescimento e desenvolvimento na perspectiva dos estudos de recepção publicitária.

Tal situação compromete os trabalhos (ainda poucos) desenvolvidos recentemente sobre recepção publicitária. A falta de referências sólidas e de experimentações dos aspectos metodológicos torna as pesquisas carentes de modelos que permitam observar empiricamente o "objeto" de modo eficaz, bem como compreender as complexas relações e interações entre as intenções de quem planeja a apresentação publicitária de uma mercadoria (produto ou serviço) e os seus potenciais consumidores. Como consequência, percebemos, ainda, uma "pobreza do instrumental teórico-metodológico empregado nas investigações que abordavam o fenômeno publicitário" (MAZETTI, 2011, p.2), visto a incipiência da articulação teórica com outras disciplinas.

Buscamos, então, discutir a publicidade dentro do contexto social contemporâneo com o objetivo de lançar perspectivas que superem ou, ao menos, contribuam para a superação da realidade apresentada. Entendemos que a análise isolada na mensagem publicitária ou no veículo escolhido estrategicamente para transmiti-la não é capaz de revelar o potencial do discurso em questão junto à sociedade, pois é somente através da recepção/consumo dos anúncios que, efetivamente, os sentidos são gerados e incorporados pelos atores sociais. Portanto, consideramos fundamental a análise do contexto cultural e social, visto que é nele que ocorrem a validação e a reprodução do discurso publicitário.

A comunicação publicitária caracteriza-se como um sistema de movimento contínuo, ininterrupto e de mútua interação entre a esfera da produção e da recepção. No processo, circulam valores e desejos de interesses pessoais e sociais, tanto dos consumidores quanto dos produtores do discurso, perpassados pelas lógicas econômicas. Isto é, "se, em um momento as práticas de recepção oferecem subsídios para determinar a produção dos anúncios, em outro, a 
estrutura econômica e as práticas de produção condicionam sua recepção" (PIEDRAS, 2009, p.80).

De um lado, o da produção, encontram-se as lógicas capitalistas de mercado, que, invariavelmente, impõem as suas regras, bem como as próprias da criação (interesses comerciais e corporativos, ideologias pessoais e das empresas, aspectos tecnológicos), as quais submetem e condicionam a mensagem publicitária. De outro, o da recepção, estão os interesses do público-alvo e a sua cultura, mediados por inúmeras particularidades dos sujeitos (Ex: classe, gênero, faixa etária), que, ao serem detectadas, através de pesquisas de mercados e tendências, subsidiam a criação publicitária.

A perspectiva cultural da recepção publicitária justifica-se pelo nosso interesse de observar a relação de receptores com os anúncios. Isso não quer dizer que desconsideramos as questões econômicas que envolvem a relação, mas que propomos um recorte para a análise do processo da comunicação publicitária. Sendo assim, o objetivo não é apresentar uma abordagem materialista da narrativa publicitária, nem tampouco desvinculá-la do capital. A ideia é pensá-la a partir da relação direta com a cultura e os seus agentes, haja vista que, em nossa compreensão, é no ato da recepção, aqui considerado como o espaço de "consumo" dos anúncios, que, efetivamente, há o encontro e a relação entre a mensagem publicitária e os atores sociais. Ou seja, a recepção é o momento/espaço de (re)produção de (novos) sentidos.

A publicidade é um processo em que sujeito e produto definem-se mutuamente (ROCHA, 2006). Entretanto, adaptamos e ampliamos tal afirmação à noção de que, assim como a mensagem publicitária influencia o comportamento de quem consome o anúncio, também é inspirada pela cultura vivida dos indivíduos. Isso nos permite pensar que a publicidade é um produto midiático e cultural, que com as suas representações sociais, é capaz de, através do seu consumo simbólico - a recepção -, servir como referência para que os indivíduos construam as próprias identidades, independentemente da aquisição e dos usos de produtos e serviços adquiridos.

Para além do estímulo à compra, a publicidade ocupa um espaço privilegiado na cultura contemporânea. Ela é capaz de explicar a ordem social e simbólica de períodos históricos, tendo em vista as suas incontáveis representações de valores, comportamentos, situações, acontecimentos e sujeitos. A narrativa publicitária insere-se cotidianamente nas relações humanas e sociais e reinventa-se junto aos indivíduos, tornando-se, assim, um elemento que ultrapassa os limiares econômicos, formando um sistema conceitual que circula na ordem coletiva, "um caminho para o entendimento de modelos de relações, comportamentos e da expressão ideológica dessa sociedade” (ROCHA, 1995, p.29). 
Com base nessa concepção, o discurso publicitário oferece aos receptores mais do que produtos e serviços. Interesses financeiros à parte, ele disponibiliza aos atores diversas representações que se articulam, se reinventam e se reproduzem nas relações cotidianas (quase sempre de maneira imperceptível). É composto por modos de ser e socializar, estilos de vida, opiniões, valores e manuais de etiqueta que transcendem a materialidade e o financeiro, colocando-se à disposição de uso, independentemente de sexo, raça ou classe. Mazetti reitera essa abordagem, afirmando que: "se uma das principais funções da publicidade seria verbalizar os poderes comunicativos dos bens de consumo, as representações sociais produzidas pelo discurso publicitário não se limitariam a esfera das mercadorias" (2011, p. 8). Portanto, a mensagem publicitária é passível de apropriação, mesmo sem o uso dos produtos, e serve como suporte e orientação para que os indivíduos organizem-se, estabeleçam relações e construam as suas identidades.

\section{DIFICULDADES METODOLÓGICAS PARA PENSAR A RECEPÇÃO PUBLICITÁRIA}

A nossa intenção é apontar e discutir alguns aspectos metodológicos que consideramos decisivos para investigar a recepção da publicidade. Os questionamentos foram suscitados a partir da realização do estudo empírico intitulado "Masculinidade em anúncio(s): recepção publicitária e identidade de gênero" que, ao nosso ver, apontou desafios para novas pesquisas que se proponham a compreender as relações dos atores sociais com as representações promovidas pelos anúncios publicitários contemporâneos. A discussão parte de dificuldades enfrentadas na realização da pesquisa, nas quais reconhecemos aspectos importantes a serem debatidos no âmbito da recepção publicitária. O fato reforça o quanto o campo de estudos da recepção ainda possui desafios no que diz respeito à necessidade de desenvolverem-se ferramentas metodológicas mais eficientes e capazes de contemplar a análise da relação sujeito/anúncios.

\subsection{O fluxo publicitário, a apropriação de representações e a baixa memória do receptor}

O primeiro aspecto refere-se à questão do fluxo publicitário caracterizar-se como algo contínuo e concomitante em diversos suportes midiáticos. Através da circulação de um conjunto multiforme de anúncios, a publicidade se configura "como um discurso contínuo, e não como campanhas particulares, cuja análise isolada não revela a totalidade das dimensões com as quais essa forma de comunicação se articula" (PIEDRAS, 2009, p. 95). Portanto, tratase de um heterogêneo "mundo dos anúncios" (ROCHA, 1995), que são disponibilizados 
cotidianamente, abarcando, desde as lógicas da produção e dos meios técnicos, até as contradições da recepção.

Por conta do contexto, nos deparamos com um verdadeiro desafio metodológico para os estudos de recepção da publicidade: apreender o fluxo dos anúncios, sem que, ao mesmo tempo, ocorra a sua ruptura e o deslocamento do objeto (anúncio ou campanha) de investigação para fora do local de recebimento. Do contrário, acreditamos que a análise isolada pode gerar concepções divergentes ou superficiais sobre a relação entre receptores e anúncios. Ainda, esse impasse é reforçado pelo fato de os meios e os formatos serem parte estratégica da mensagem e, portanto, da persuasão do público. No entanto, embora entendamos que o caminho que propomos seja o mais adequado, é preciso reconhecer a dificuldade e a ausência de instrumentos metodológicos capazes de abarcar todo ou, até mesmo, parte da continuidade do fluxo publicitário. Além disso, é necessário considerarmos o tempo e o recurso humano, que são restritos para a realização de pesquisas em programas de pós-graduação.

Também sobre o fluxo publicitário, destacamos questões referentes à composição do corpus de análise em pesquisas de recepção. Se pensarmos apenas na observação e no recolhimento de todos os anúncios, ainda que limitados a uma marca ou a um segmento de produto circulante no fluxo publicitário, a análise já requereria um imenso esforço. Assim, a inserção no campo poderia ser inviável, no que se refere ao acompanhamento da amostra. Isso porque, mesmo que ela seja reduzida, no contexto diário, o fluxo contínuo extrapola os tradicionais espaços publicitários e está inserido cotidianamente em diferentes locais, muitas vezes de forma não explícita. Essa situação já foi detectada por Casaqui (2011), quando o autor tratou do processo de publicização.

Diferentemente da telenovela ou do telejornalismo, que possuem espaços e horários de veiculação determinados na programação, conhecidos previamente pelos receptores (o que sugere uma ritualidade no consumo dos produtos midiáticos), a publicidade está pulverizada dentro e fora dos intervalos comerciais. É o caso do merchandising, das peças e chamadas que circulam nas mídias digitais, nos outdoors e luminosos, nas páginas dos jornais e das revistas e, ainda, de mais uma infinidade de possibilidades de promoção das marcas e dos produtos que nos interpelam cotidianamente. Além disso, há uma incontável quantidade de segmentos e tipos de publicidades veiculadas constantemente, fator que atua como uma dificuldade a mais no processo investigativo de uma temática específica. Por exemplo, a realização de uma etnografia da mídia televisiva sobre um produto midiático, em um período determinado, não garante a veiculação de anúncios que tratem da representação do homem com foco no 
exercício da paternidade ou em qualquer outro assunto de interesse investigativo do pesquisador.

Para Piedras (2009), o fluxo na publicidade é permitido por uma de suas características, a intertextualidade. Ela compreende o diálogo entre os discursos, que se reconhecem quando movimentados no universo publicitário, possibilitando a criação de uma rede de significados. Isso ocorre a partir da conexão de diversos anúncios em circulação, de anunciantes e de produtos distintos, além da temporalidade e dos meios veiculados que, orquestrados conjuntamente, dão sentido ao todo. Do mesmo modo, a fragmentação, outra característica da publicidade, contribui para a noção sobre fluxo, no sentido de que os anúncios são pulverizados entre os meios conforme os interesses do anunciante. Nesse caso, são os diferentes discursos dos anúncios (aparentemente não lineares e desconexos) que se vinculam dentro de um enredo publicitário maior, o qual compreende as outras peças da campanha, a programação do veículo inserido e o imaginário social de quem os recebe e (re)significa.

Nesse sentido, apontamos nosso próximo aspecto de preocupação metodológica, que diz respeito à compreensão do funcionamento e a incorporação das representações sociais pelos sujeitos. Isso porque elas somente ganham sentido dentro do fluxo, uma vez que a publicidade caracteriza-se pela intertextualidade. Portanto, o entendimento da publicidade como uma das principais fontes promotoras de representações na contemporaneidade deve ser feito a partir da análise do fluxo dos anúncios. Afinal, a estabilização e a incorporação de representações pelos receptores ocorrem a partir da ampla distribuição nos diferentes anúncios, em um período relativamente longo, só assim passando a integrar as identidades dos atores sociais e da nossa cultura. Essa noção também propõe o questionamento sobre em qual momento/parte do fluxo a recepção as representações são, de fato, aceitas e incorporadas. Por isso, percebemos a importância da observação do todo para que possamos fazer inferências, ainda que limitadas, sobre o processo de "consumo" da publicidade.

Em termos práticos de reconhecimento, é necessário considerar a complexidade que envolve o universo publicitário - tanto em termos dos sentidos agenciados, no âmbito da produção, quanto da articulação com o mundo social e seus receptores -, fato que exige certo tempo e dinâmica para que as pessoas assimilem e aceitem tais representações. Ou seja, queremos dizer que as representações (re)produzidas pelo discurso publicitário somente ganham sentido e são naturalizadas pelo imaginário social ao longo de seu processo de circulação na sociedade. Mais do que em movimento, é preciso que estejam presentes em 
diferentes plataformas midiáticas (impressas, audiovisuais, digitais, etc.), atuando de modo ininterrupto e concomitante, no sentido de um fluxo publicitário (PIEDRAS, 2009).

Ainda que sejam inúmeros os desafios metodológicos e de investigação na área da recepção publicitária, pesquisar as representações organizadas nos anúncios "é importante para decifrar o imaginário que informa as práticas de consumo. A publicidade é a narrativa que dá sentido ao consumo e que está, seguramente, entre as principais produtoras de sistemas simbólicos presentes em nosso tempo" (GASTALDO, 2013, p.13). Para isso, o contato com os atores sociais é fundamental, visto que é no espaço da recepção que as representações são interpretadas e inseridas em nossa cultura, estimulando o consumo e constituindo as identidades.

\begin{abstract}
A publicidade traduz a produção para que esta possa virar consumo, e ensina modos de sociabilidade enquanto explica o quê, onde e como consumir. [...] Por isso, são fundamentais os estudos sobre o discurso publicitário, a pesquisa das representações que ele aciona, a análise da lógica por meio da qual se estrutura, os significados que disponibiliza. (GASTALDO, 2013, p.11-12).
\end{abstract}

Com base na dissertação de mestrado usada como referência, destacamos o terceiro ponto de reflexão deste trabalho. Desde os primeiros passos metodológicos ${ }^{3}$, com o estudo exploratório do campo, detectou-se a pouca memória dos receptores sobre os anúncios publicitários veiculados pelo fluxo cotidianamente. Para surpresa, os sujeitos não foram capazes de recordar, sequer, as publicidades vistas no dia em que foram questionados. A maior lembrança esteve relacionada àquelas publicidades épicas, que marcam a história da comunicação brasileira, como as do Garoto Bombril ${ }^{4}$ e as do Tio da Sukita ${ }^{5}$, ou a alguma outra bastante específica relacionada à sociabilidade do receptor. Contudo, na maioria das

\footnotetext{
${ }^{3}$ Inicialmente, a pesquisa contou com a aplicação de formulários com quarenta homens de diferentes profissões, classes sociais e gerações. Posteriormente, foi definida uma amostra de dez homens, de classe popular e alta, o corpus de anúncios e as categorias empíricas de análise. Na etapa seguinte, foram realizadas entrevistas em profundidade, de caráter híbrido (semiestruturada e com perguntas abertas e fechadas).

${ }^{4}$ Personagem criado em 1978 pela agência DPZ Brasil, interpretado pelo ator Carlo Moreno, "um garotopropaganda que entraria para o Guinness Book como o de maior tempo de permanência no ar, a partir do décimo sexto ano de execução e mais de 340 filmes. O personagem tímido e que dizia que o produto tinha 'um negócio' na fórmula fez de Moreno celebridade do dia para noite". Disponível em: $<$ http://exame.abril.com.br/marketing/noticias/o-nascimento-do-garoto-bombril>. Acesso em: 17 de fev. 2014.

5 "O comercial usa de maneira bem humorada e não-apelativa de dois personagens estereotipados que são comuns na sociedade brasileira: a bela jovem adolescente, interpretada por Michelly Machri, com aparência delicada e aparentemente inocente; e o coroa cinquentão, vivido por Roberto Arduin, que, apesar da idade, faz de tudo para parecer jovem e se sentir atraente. A forma como os dois interagem, a insinuação barata do homem sobre a garota (situação também comum na sociedade brasileira) e a quebra de expectativa quando ele é chamado de 'tio', associa a marca a jovens de atitude e decididos e é reforçada pela locução: 'Quem bebe Sukita não engole qualquer coisa"”. Disponível em: <http://www.vitaminauff.com.br/tio-sukita-historia/>. Acesso em: 17 de fev. 2014.
} 
vezes, tais exemplos não corresponderam ao assunto de interesse na pesquisa ou às suas categorias, o que se configura como um desafio para o processo de investigação.

A baixa lembrança pode ser justificada a partir do próprio fluxo, consequência do ininterrupto bombardeio de mensagens publicitárias. Isso revela que "a fugacidade é uma das características das representações midiáticas" (GASTALDO, 2013, p.21) e, portanto, reitera o sentido social de que a promoção pela publicidade é construída coletivamente, dentro do fluxo dos anúncios. Essa situação contrasta com o grande retorno que as empresas anunciantes têm, evidenciado pelos crescentes investimentos no setor de marketing e propaganda ${ }^{6}$. Então, não há dúvida: quando os anúncios são bem empregados, há êxito na atividade publicitária, não apenas mercadológica, mas em servir de suporte para a formação social e cultural dos sujeitos na contemporaneidade. Conforme afirma Gastaldo (2013), "ouse-se tudo na publicidade, exceto perder dinheiro e espaço no mercado por um anúncio equivocado" (p.23).

Ainda, nos estudos de recepção, a questão da pouca memória alerta para a importância de não restringirmos metodologicamente nossas pesquisas a um determinado anúncio ou campanha, especialmente quando o objetivo é tratar da narrativa publicitária como uma fonte de representações - sobre o homem, a mulher, o brasileiro, o idoso, o jovem, entre inúmeras outras. Como observado empiricamente, o sentido é construído pelo receptor a partir de um conjunto diário e contínuo de publicidades recebidas. Dessa forma, acontece a apropriação dos modos de ser, estilos de vida, padrões estéticos e demais referências para a formação das identidades.

[...] o investimento anual em publicidade no Brasil e no mundo está constantemente crescendo. [...] Entretanto, considerar a publicidade somente sob o ponto de vista do seu papel de "ferramenta mercadológica" significa eliminar toda a dimensão social, cultural e simbólica presente no discurso publicitário. (GASTALDO, 2013, p.25).

Cada vez mais é necessário analisarmos a recepção da publicidade, considerando-se os diversos meios, inclusive, como forma de elucidar o processo de publicização e compreender, claramente, o momento/meio em que os sujeitos, de fato, são mais influenciados e incorporam as representações. Ressaltamos, nesse sentido, que "o discurso publicitário só vai fazer referências, portanto, ao que já está dado e é hegemonicamente consensual no contexto do "público-alvo"” (GASTALDO, 2013, p.23). É devido a isso que ele tem se configurado, historicamente e na maioria dos casos, como um discurso conservador. Por conseguinte,

\footnotetext{
6 "Em 2013, os investimentos publicitários brasileiros cresceram 19\% na comparação com 2012", apontam os dados publicados pelo Instituto Brasileiro de Opinião Pública e Estatística - IBOPE. Disponível em: $<$ http://www.ibope.com.br/pt-br/conhecimento/Infograficos/Paginas/Investimentos-publicitarios-de-2013.aspx. $>$ Acesso em: 21 de fev. 2014.
} 
segundo o autor, definir a publicidade como "revolucionária" é um equívoco, pois ela é baseada em pesquisas mercadológicas e de comportamento do consumidor, as quais reiteram os interesses latentes na sociedade. Isto é, as representações construídas na publicidade são resultado do desejo e das demandas sociais, as quais, por fim, tornam-se estampadas através de um discurso idealizado.

\section{CONSIDERAÇÕES FINAIS}

Com base no cenário teórico e metodológico apresentado sobre o campo de pesquisa em publicidade, sobretudo na recepção, reiteramos a importância e a necessidade de tratar o fenômeno publicitário a partir do ponto de vista de sua articulação com o contexto social e cultural. É necessário extrapolar as questões técnicas da mensagem e os aspectos econômicos da produção. A intenção não é produzir uma crítica gratuita ou desconsiderar as pesquisas, anteriores, mas de contribuir para tornar a nossa área um espaço científico frutífero e sólido na área da Comunicação. Dessa forma, acreditamos que, através do criativo emaranhado de anúncios que nos interpelam cotidianamente (e muito dizem sobre nós, atores sociais), seja possível refletir sobre a sociedade em que vivemos.

Ainda, entendemos que propor discussões sobre a configuração do objeto de estudo é fundamental para o desenvolvimento das pesquisas, especialmente, quando se trata de uma área que ainda está em processo de consolidação acadêmica, como no caso da publicidade. Consideramos que refletir sobre os desafios metodológicos é um caminho perspicaz, além de necessário, para, a partir das dificuldades e achados empíricos, buscar soluções que favoreçam e tragam mais precisão ao processo investigativo da recepção publicitária.

Destacamos que o objetivo do trabalho não foi o de encerrar a discussão ou propor definições. Pelo contrário, nossa proposta foi a de levantar questões relacionadas ao fluxo publicitário, identificadas em outro momento. Afinal, o fluxo "viabiliza o entendimento da forma cultural e tecnológica da publicidade na sua configuração atual, tanto em termos de sua veiculação através dos diferentes suportes (ou meios) quanto sobre a relação instituída com os sujeitos nas práticas de recepção" (PIEDRAS, 2009, p.92).

Dessa maneira, procuramos trazer para o debate os desafios apontados, com o intuito de, conjuntamente, encontrarmos trajetos metodológicos adequados que, ao menos, deem conta da análise do fenômeno publicitário contemporâneo. Sobretudo, buscando compreender a apropriação (negociação ou resistência) das representações sociais propostas pelos anúncios

e em que medida eles atuam como referências para que os sujeitos construam as suas múltiplas identidades. 


\section{REFERÊNCIAS}

CASAQUI, V. Por uma teoria da publicização: transformações no processo publicitário. Significação, 36, 2011, p. 131-151. Disponível em:

http://www.usp.br/significacao/pdf/6_Significacao\%2036_Vander\%20Casaqui.pdf. Acesso em: 23 abr 2014.

FRANÇA, V. R. V. Crítica e Metacrítica: contribuição e responsabilidade das teorias da comunicação. 2013. Anais... Disponível em: $<$ http://compos.org.br/data/biblioteca_2059.pdf. Acesso em: 14 mar 2014.

GASTALDO, É. Publicidade e Sociedade: uma perspectiva antropológica. Porto Alegre: Sulina, 2013.

JACKS, N. A. A publicidade vista pela academia: tendência dos anos 90. In: RAMOS, R (org.). Mídia, textos e contextos. Porto Alegre: PUCRS, 2002. p.205-209.

JACKS, N. A; PIEDRAS, E. R. A recepção da publicidade: um campo incipiente (análise de pesquisas produzidas entre 1990 e 2009). In: TRINDADE, E.; PERES, C. (orgs.). Há momentos em que precisamos parar para pensar os rumos da publicidade contemporânea. Salto, SP: Editora Schoba, 2010. E-book.

LONDERO, R. Um breve panorama das teorias da publicidade. 2011. Anais... Disponível em: $<$ http://confibercom.org/anais2011/pdf/312.pdf. $>$. Acesso em 18 abr 2014.

MAZETTI, H. As aporias da publicidade: entre a abordagem socioeconômica e a perspectiva cultural. 2011. Anais... Disponível em: $<$ http://pucposcom-rj.com.br/wpcontent/uploads/2011/11/mazetti.pdf $>$. Acesso em: 13 mar 2014.

OLIVEIRA-CRUZ, M. C. B. F. Notas para pensar a recepção publicitária no âmbito da midiatização. Alceu (PUCRJ), 14, 2013. P.5-19. Disponível em:

$<$ http://revistaalceu.com.puc-rio.br/media/1alceu27.pdf. $>$

PIEDRAS, E. R. Fluxo publicitário. Anúncios, produtores e receptores. Porto Alegre: Editora Saraiva, 2009.

ROCHA, E. Magia e capitalismo. Um estudo antropológico da publicidade. São Paulo: Editora Brasiliense, 1995.

Representações do consumo. Estudos sobre a narrativa publicitária. Rio de Janeiro: Ed. PUC-Rio: Mauad, 2006.

SANTOS, F. B. Masculinidade em anúncio(s): recepção publicitária e identidade de gênero. Dissertação (Mestrado em Comunicação). 2012. Universidade Federal de Santa Maria, Santa Maria, Brasil.

SODRÉ, M. Sobre a episteme comunicacional. Matrizes, 1, 1, 2007. P.15-26. Disponível em: $<$ http://www.matrizes.usp.br/index.php/matrizes/article/download/38/61. $>$. Acesso em: 27 mar 2014. 
Original recebido em: 03/02/2009

Aceito para publicação em: Novembro de 2013

\section{Sobre o autor}

Filipe Bordinhão dos Santos é professor Substituto do Departamento de Ciências da Comunicação e Doutorando em Comunicação pelo Programa de PósGraduação em Comunicação da Universidade Federal de Santa Maria. Publicitário e Mestre em Comunicação pela UFSM. 